neuroimaging, and thrombolysis. JAMA neurology. 2013;70(1):51-7.

5. Kwon SU, Kim JS, Lee JH, Lee MC. Ischemic stroke in Korean young adults. Acta Neurol Scand.
2000;101:19-24.

6. Lee TH, Hsu WC, Chen CJ, Chen ST. Etiologic study of young ischemic stroke in Taiwan. Stroke. 2002;33(8):1950-1955.

\title{
LIÊN QUAN GIỮA THUỐC LÁ VÀ BỆNH UNG THƯ PHỔI
}

\author{
GS.TS. Ngô Quý Châu \\ Giám đốc chuyên môn Bệnh viện đa khoa Tâm Anh Hà Nội, \\ chủ tịch hội Hô Hấp Việt Nam
}

Ung thư phổi là căn bệnh có tỷ lệ mắc và tử vong hàng đầu trong số các bệnh ung thư ở cả hai giới. Theo điều tra của Tồ chức nghiên cứu toàn cầu về ung thư (GLOBOCAN) năm 2020 thì số ca mắc mới ung thư phổi trong một năm là 2.206.771 đứng thứ hai chỉ sau ung thư vú và số ca tử vong trong một năm vì ung thư phổi là 1.796.144 đứng ở vị trí hàng đầu trong tử vong vì ung thư.

Hút thuốc lá là nguyên nhân chủ yếu gây ung thư phổi, cứ 10 ca mắc ung thư phổi thì có $9 \mathrm{ca}$ là có liên quan đến hút thuốc lá.
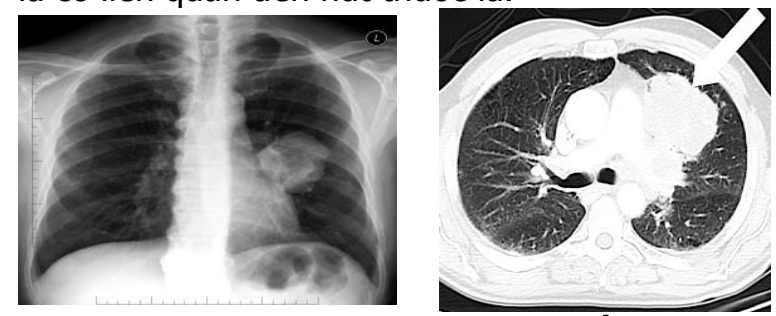

Hình 1. Hình ảnh khôii u phổi trái

Các phân tích hóa học cho thây trong khói thuốc lá tồn tai trên 7000 loai hóa chất tồn tai dưới hai dạng: dạng hạt và dạng khí. Nhiều thực nghiệm trền súc vật đã chứng minh thành phần hạt của khói thuốc lá là chất gây ung thư ở đường hô hấp và các tổ chức khác. Có 69 chất trong khói thuốc lá đã được chứng minh là nguyên nhân gây ung thư, chủ yếu là các chất thơm có vòng như Benzopyren, nitrosamin, arsenic, nickel, chrom các đồng vị phóng xạ... Các chất này tác động lên niêm mạc đường hô hấp gây nên tình trạng viêm mạn tính, phá hủy tổ chức và biến đổi tế bào dẫn đến ác tính hóa.

Các bằng chứng khoa học từ giữa thế kỷ 20 đã cho thấy mối liên quan đáng kể giữa hút thuốc lá chủ động và ung thư phổi. Nghiên cứu của Doll và Hill năm 1954 ở Anh cho thấy những người hút thuốc lá có nguy cơ bị ung thư phổi cao gấp 14 lần so với người không hút thuốc lá. Năm 1986, cơ quan nghiên cứu quốc tế về ung thư khi nghiên cứu mối quan hê giữa thuốc lá và ung thư đã đưa ra kết luận hút thuốc là nguyên nhân nổi bật của ung thư phổi trên toàn thế giới. Không chỉ hút thuốc lá chủ động mà hút thuốc thụ động cũng gây ung thư phổi ở những người lớn chưa bao giờ hút thuốc. Việc phơi nhiễm với khói thuốc ở nhà hoăc nơi làm viêc làm tăng nguy cơ ung thư phổi lển 20-30\%. Mỗi năm hút thuốc lá thụ động gây ra hơn 7300 trường hợp tử vong do ung thư phổi ở người không hút thuốc tại Mỹ.

Nguy cơ phát triển ung thư phổi gia tăng với thời gian hút thuốc lá và số lượng thuốc lá hút hàng ngàyy. Không có ngưỡng hút thuốc mà việc phơi nhiễm không có rủi do. Các yếu tố khác có thể ảnh hưởng đến khả năng phát triển ung thư phổi ở người hút thuốc lá bao gồm tuổi bắt đầu hút thuốc, mức độ hít khói thuốc, hàm lượng nicotine và nhựa thuốc lá (tar) và việc sử dụng thuốc lá không đầu lọc. Tỷ lệ nguy cớ tương đối xuất hiện ung thư phổi giữa người hút thuốc và không hút thuốc là 15 nói chung và là 25 đối với người nghiện thuốc lá nặng. Nguy cơ tích luỹ ung thư phổi ở những người nghiện thuốc lá nặng có thể tới $30 \%$ khi so sánh với nguy cơ $1 \%$ hoặc thấp hơn ở những người không hút thuốc bao giờ.

Việc cai thuốc lá giúp giảm nguy cơ phát triển ung thư phổi so với tiếp tục hút thuốc, nguy cơ ngày càng giảm hơn khi thời gian duy trì cai thuốc càng dài. Tuy nhiên, thậm chí sau một thời gian cai thuốc dài, nguy cơ ung thư phổi ở những người đã từng hút thuốc vẫn cao hơn so với những người không bao giờ hút thuốc.

Nhiều nghiên cứu cũng đã cho thấy việc cai thuốc lá sau khi chẩn đoán ung thư phổi có liên quan với việc cải thiện sức khỏe. Trong một tổng quan hệ thống phân tích gộp, việc tiếp tục hút thuốc ở những bệnh nhân được chẩn đoán ung thư phổi giai đoạn sớm hoặc giai đoạn khu trú có liên quan với sự gia tăng nguy cơ tử vong do mọi nguyên nhân, tái phát ung thư, và sự phát triển một ung thư nguyên phát ở cơ quan khác.

Cai thuốc lá giúp giảm nguy cơ biến chứng sau phẫu thuật ung thư phổi. Một nghiên cứu đoàn hệ hồi cứu đã cho thấy tỷ lệ sống sót ở 
tuần thứ 120 sau phẫu thuật ung thư phổi không tế bào nhỏ ở những người không hút thuốc và đã cai thuốc là $60-70 \%$ so với chỉ $25 \%$ ở những người tiếp tục hút thuốc. Có nhiều giải thích cho sự khác biệt này bao gồm cả sự gia tăng biến chứng từ điều trị, tái phát ung thư và sự xuất hiện các khối u mới. Cai thuốc sớm hơn thì tốt hơn, với mỗi tuần cai thuốc sớm hơn sẽ giảm nguy cơ biến chứng sau phẫu thuật thêm 19\%.

Cai thuốc lá cũng giúp cải thiện đáp ứng của bệnh nhân ung thư phổi với điều trị hóa chất và xạ trị. Hút thuốc lá ảnh hưởng đến chuyển hóa thuốc. Thuốc ức chế thụ thể yếu tố tăng trưởng biểu bì (EGFR) erlotinib được chuyển hóa ở mức độ cao hơn ở những người hút thuốc do sự kích thích của enzym cytochrome P450, CYP1A1/1A2. Những người hút thuốc mắc ung thư phổi không tế bào nhỏ có ít đột biến EGFR kích hoạt hơn và những thay đổi gen điều khiển anaplastic lymphoma kinase làm giảm khả năng đáp ứng với các thuốc ức chế EGFR. Một nghiên cứu trên 83 bệnh nhân mắc ung thư phổi không tế bào nhỏ được điều trị xạ trị, hút thuốc lá là một yếu tố nguy cơ độc lập cho sự tiến triển viêm phổi sau xạ trị và nhiếm trùng phổi. Tỷ lệ sống trung bình và sống sau 2 năm cũng lâu hơn ở những người không hút thuốc. ${ }^{21}$ Cai thuốc lá cũng giúp cải thiện chất lượng cuộc sống và bậc thang thể trạng ở những người hút thuốc mắc ung thư phổi.

Mặc dù việc cai thuốc đóng vai trò rất quan trọng đối với những người hút thuốc mắc ung thư phổi, tuy nhiên có khoảng $10-13 \%$ bênh nhân vẫn tiếp tục hút thuốc ở thời điểm 6 tháng sau khi chẩn đoán ung thư phổi. Điều trị cai nghiện thuốc lá cho những bênh nhân mắc ung thư phổi cần kết hợp tư vấn thay đổi hành vi với thuốc điều trị hỗ trợ cai nghiện thuốc lá và theo dõi thường được kểt hợp với các lần thăm khám điều trị bệnh, nội dung tư vấn được thiết kế cụ thể để tăng cường sự tự tin cai thuốc, giảm trầm cảm, giúp bệnh nhân tăng khả năng cai thuốc lá thành công.

Tóm lại, hút thuốc lá chủ động và thụ động là nguyên nhân chủ yếu gây ung thư phổi. Người hút thuốc lá có nguy cơ bị ung thư phổi cao gấp 15- 25 lần so với người không hút. Hút thuốc lá càng nhiều năm, số lượng thuốc lá hút càng nhiều thì nguy cơ mắc ung thư phổi càng lớn. Việc cai thuốc lá giúp giảm nguy cơ phát triển ung thư phổi, giảm nguy cơ biến chứng sau phẫu thuật ung thư phổi, cải thiện đáp ứng của bệnh nhân ung thư phổi với điều trị hóa chất và xạ trị. Vì vây cần điều trị cai nghiên thuốc lá cho tất cả những người nghiện thuốc là và những bệnh nhân mắc ung thư phổi cũng như các bệnh khác liên quan thuốc lá.

\section{TÁC HẠI CỦA KHÓI THUỐC LÁ VớI HỆ HÔ HẤP}

\section{TÓM TẮT}

Mặc dù phổi là bộ phận của cơ thể được bảo vê bởi hể thống miễn dịch chung và bởi cơ chế tự bảo vể tại phổi, nhưng vẫn bi tác động của các chất độc hại có trong khói thuốc lá và tự môi trường. Tác hại của khói thuốc lá tới nhiều bộ phận của cơ thể và gây nhiều bệnh lý nguy hiểm đến tính mang. Ngay tại phổi, 2 bệnh hay gặp có liên quan đến thuốc lá là ung thư phổi và bệnh phổi tắc nghẽn mạn tính. Đây là 2 bệnh trong nhóm nguyên nhẩn hàng đầu gây tử vong trên toàn thế giới.

\section{SUMMARY}

\section{THE HARMFUL EFFECT OF SMOKING ON} THE RESPIRATORY SYSTEM

Even though being protected by genetically immune system and itself, lung is damaged by toxics in smoke and others from enviroments. Smoking can cause serious harm to all the body and produce many dangerous diseases. In lung, 2 diseases - lung cancer and chronic obstructive lung disease are closely concerning to smoke and being in the leading causes

\section{Đinh Ngoc Sỹ \\ Tổng hội Y học Việt Nam}

of death on the words.

Key words. Harm, smoking, lung cancer, COPD

\section{I. ĐĂT VẤN ĐỀ}

Như chúng ta đã biết, thuốc lá là một sản phẩm được dùng trong đời sống của loài người từ rất xa xưa. Trải qua nhiều thế kỉ, cùng với sự thay đổi của khoa học- công nghệ cũng như nhu cầu cuộc sống, khiến cho thuốc lá đã thay đổi không ngừng về chất lượng cũng như chủng loại, mẫu mã cũng như hình thái sử dụng. Mặc dù hiểu biết của con người về những tác động có hại của thuốc lá đã rõ ràng, song thuốc lá vẫn tồn tại như một phần không thể thiếu trong cuộc sống xã hội. Tại sao vậy? Có 2 lí giải cho sự tồn tại đó. Trước tiên phải nói đến đó là nhu cầu của người sử dụng thuốc lá do một số chất gây nghiện có trong thành phần khói thuốc lá (nicotin) khiến con người lệ thuộc vào nó. Thứ đến là do nguồn lợi khổng lî̀ mang tới từ ngành 